\title{
Better clinical decision making and reducing diagnostic error
}

\author{
P Croskerry, GR Nimmo \\ ${ }^{1}$ Clinical Consultant in Patient Safety and Professor in Emergency Medicine, Dalhousie University, Halifax, Nova Scotia, Canada; ${ }^{2}$ Consultant \\ Physician in Intensive Care Medicine, Western General Hospital, Edinburgh, UK
}

\begin{abstract}
This review is based on a presentation given by Dr Nimmo and Professor Croskerry at the RCPE Patient Safety Hot Topic Symposium on 19 January 201 I.

ABSTRACT A major amount of our time working in clinical practice involves thinking and decision making. Perhaps it is because decision making is such a commonplace activity that it is assumed we can all make effective decisions. However, this is not the case and the example of diagnostic error supports this assertion. Until quite recently there has been a general nihilism about the ability to change the way that we think, but it is now becoming accepted that if we can think about, and understand, our thinking processes we can improve our decision making, including diagnosis. In this paper we review the dual process model of decision making and highlight ways in which decision making can be improved through the application of this model to our day-to-day practice and by the adoption of de-biasing strategies and critical thinking.
\end{abstract}

KEYWORDS Critical thinking, decision making, diagnosis, patient safety

DECLARATION OF INTERESTS No conflict of interests declared.

\author{
Correspondence to P Croskerry, \\ Department of Emergency \\ Medicine and Division of Medical \\ Education, Faculty of Medicine, \\ Dalhousie University, QE II - \\ Health Sciences Centre, Halifax \\ Infirmary, Suite 355, 1796 Summer \\ Street, Halifax, Nova Scotia B3H \\ 2Y9, Canada
}

tel. +l 9022250360

e-mail croskerry@eastlink.ca
Everyone complains of his memory, and no one complains of his judgment.

— François de La Rochefoucauld

\section{INTRODUCTION}

How doctors think, reason and make clinical decisions is arguably their most critical skill. Importantly, it underlies a major part of the process by which diagnoses are made. In all of the varied clinical domains where medicine is practised, from the anatomic pathology laboratory to the intensive care unit, decision making is a critical activity. Yet, it is somewhat surprising that the topic is not explicitly addressed in most medical undergraduate curricula. It is generally assumed, since decision making is ubiquitous, that physicians will have automatically acquired their clinical decision making skills in the course of their training, by osmosis, example, mentorship, mimicry or other means.

Diagnostic decision making is a pivotal skill exhibited across all medical domains. If it was a reliable process and performed well, there would be little cause for concern. However, the emerging evidence suggests otherwise. Diagnostic errors are frequent and underappreciated. Although the true overall prevalence is unknown, it is estimated to be in the order of $10-15 \%$.' In the benchmark studies of medical error, it was ranked as the second leading cause of adverse events and was common in emergency medicine, internal medicine and family practice ${ }^{2-4}$ - all areas in which uncertainty about diagnosis is at its highest. These areas also share further disruptive factors in the form of interruptions and the requirement for patient handover. Specialist areas such as intensive care are also vulnerable. ${ }^{5} \mathrm{~A}$ diagnosis has usually been made and 'handed on' and its validity needs to be examined.

The imperfections of clinical reasoning in modern medicine were written about more than 60 years ago, ${ }^{6}$ but it is only quite recently that the problem has come into focus. Perhaps it is not altogether surprising that it has taken so long for the problem to attract the attention it deserves. Prior to the emergence of the Patient Safety movement, which began a little over a decade ago, the culture of silence in medicine would not readily have admitted open discussion about diagnostic failure. After all, 'diagnostic acumen', observed Nuland, was 'every doctor's measure of his own abilities' and 'the most important ingredient in his self-image'.? Another major issue was that decision making was an invisible process - something that went on inside the physician's head and, unlike a surgical or medication error, was hidden from view.

The hidden elements turn out to be mostly psychological factors. These underlie the processes of reasoning and behaviour in general. But psychology is not the province 
TABLE I Major characteristics of type I and type 2 decisionmaking processes

\begin{tabular}{|l|l|l|}
\hline Characteristic & Type I & Type 2 \\
\hline Reasoning style & $\begin{array}{l}\text { Intuitive } \\
\text { Heuristic } \\
\text { Associative } \\
\text { Concrete }\end{array}$ & $\begin{array}{l}\text { Analytical } \\
\text { Normative } \\
\text { Deductive } \\
\text { Abstract }\end{array}$ \\
\hline Awareness & Low & High \\
\hline Verbal behaviour & None to minimal & Yes \\
\hline Prototypical & Yes & No, based on sets \\
\hline Action & Reflexive, skilled & $\begin{array}{l}\text { Deliberate, } \\
\text { rule-based }\end{array}$ \\
\hline Automaticity & High & Low \\
\hline Speed & Fast & Slow \\
\hline Channels & Multiple, parallel & Single, linear \\
\hline Propensities & Causal & Statistical \\
\hline Effort & Minimal & Considerable \\
\hline Cost & Low & High \\
\hline Vulnerability to bias & Yes & Less so \\
\hline Reliability & Low, variable & High, consistent \\
\hline Errors & Common & Few \\
\hline Affective valence & Often & Rarely \\
\hline Predictive power & Low & High \\
\hline Hard-wired & May be & No \\
\hline Scientific rigour & Low & High \\
\hline Context & Specific & General \\
\hline Context importance & High & Low \\
\hline & & \\
\hline
\end{tabular}

Adapted from Dawson, ${ }^{19}$ Croskerry ${ }^{20}$ and Evans. ${ }^{21}$

of medicine, and it has not been easy for medical people to deliberate on its tenets. It might be easier if part of medical education were to include (and embrace) basic psychology theory as Redelmeier and his colleagues have suggested in an excellent series of articles on problems in clinical judgment. ${ }^{8-12}$ Arthur Elstein, recently reflecting upon a career devoted to understanding how physicians make decisions and how to help them make better ones', ${ }^{3}$ somewhat ruefully observed: 'It would be good if physicians were as well acquainted with the relevant principles of cognitive psychology as they are with comparable principles in pathophysiology.'14

Despite these obstacles, recent progress has been made. It was catalysed by the publication of two books, How doctors think: clinical judgment and the practice of medicine by Montgomery in $2006^{15}$ and How doctors think by Groopman in 2007. ${ }^{16}$ Both works provided unprecedented exposées of the soft underbelly of physicians' thinking processes and probably did more to flush the problem out into the open than a dozen learned articles in leading journals might have done. In 2008, the first of a series of annual conferences on diagnostic error was held in the $\mathrm{US}^{17}$ and led to the American Journal of Medicine dedicating a special supplement to diagnostic error in 2009. This year, the Royal College of Physicians of Edinburgh held a one-day conference on clinical decision making and patient safety, the first of its kind in the UK.

\section{MODELS OF DECISION MAKING}

Part of the problem in teaching about decision making is that, until recently, there was little agreement about the process of decision making itself. A confusing variety of paradigms existed. ${ }^{18}$ However, over the past 20 years a consensus has emerged around dual process theory as an eclectic, robust, and teachable approach. In essence, the theory proposes two distinct modes of thinking, each of which has distinctive properties (Table I). Intuitive reasoning is characterised by the 'shoot-fromthe-hip approach', or 'gut reaction'. It is fast, impulsive, effortless, reflexive, multi-channelled and may serve us well in certain situations in medicine, but it is errorprone. Analytical reasoning, by contrast, is slow, explicit, deliberate, purposeful, single-channelled and generally more reliable. The model has been applied to diagnostic reasoning ${ }^{22}$ and is illustrated in Figure $\mathrm{I}$.

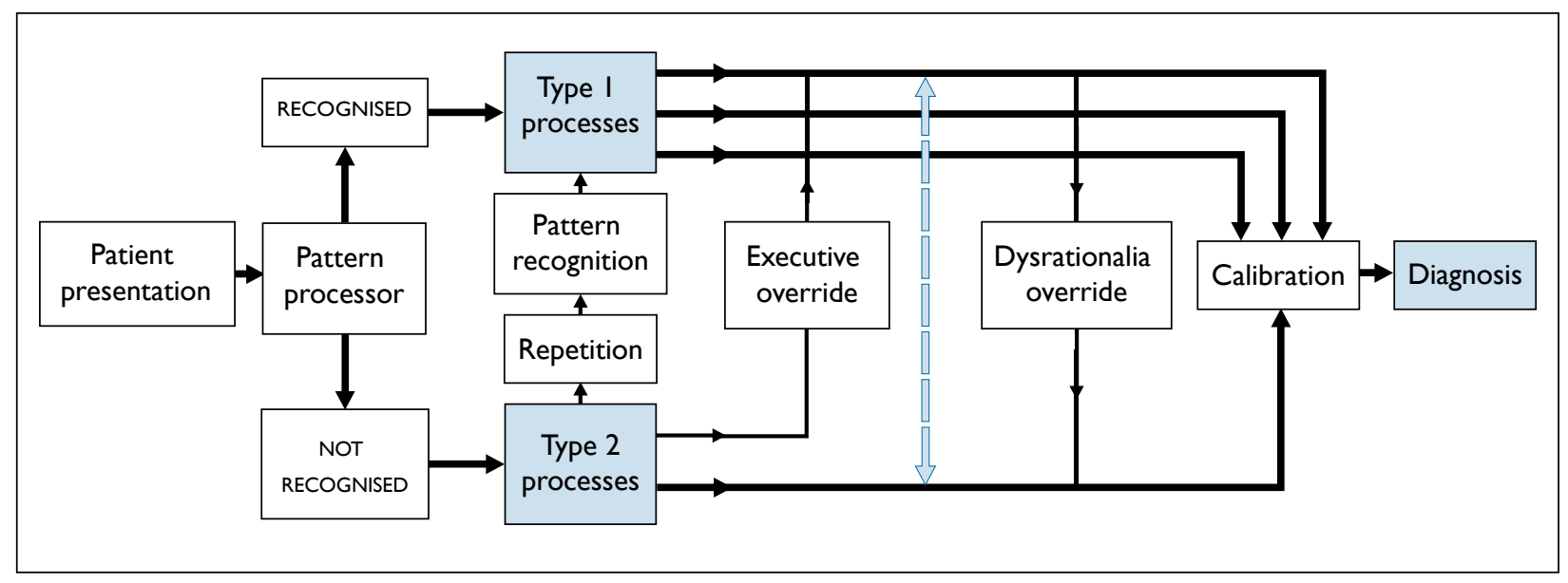

FIGURE I A diagnostic schema based on dual process theory. 
The model flows from left to right. Patients initially present with signs and symptoms of disease/illness to the clinician. If these are recognised at the outset there is a strong likelihood the intuitive mode (type I processes) will engage and a very fast decision made. In contrast, if they are not recognised, the analytic mode (type 2 processes) will be engaged and a slower, systematic effort made to determine the diagnosis. There are several operating characteristics of the model:

I. Repeated presentations to the analytic mode will eventually result in the pattern being recognised, and default to the intuitive mode occurs. Essentially, this is the process that occurs as expertise develops.

2. The analytic mode can override the intuitive mode. This is a type of executive control function - if on reflection (metacognition) the analytic mode thinks that the intuitive mode might be mistaken (first impression was wrong), or an issue needs deeper consideration, an override may occur.

3. The intuitive mode can override the analytic mode. Thus, despite knowing the best thing to do, intuition may prevail and result in an irrational act (dysrationalia).

4. The dotted blue line indicates a toggle function back and forth between the two modes. If, for example, an intuition occurs but is overridden by the analytic mode, a second intuition can result and be examined again. Thus, the system is dynamic and may oscillate back and forth to produce a well-calibrated response.

5. There is a general tendency to default whenever possible into the intuitive mode. This serves the useful function of sparing cognitive effort. It is referred to as 'the cognitive miser function'.

\section{CALIBRATING DIAGNOSTIC DECISION MAKING}

In practical, clinical terms, if a diagnosis has been made intuitively and treatment has been started there are five possible outcomes:

I. The diagnosis is correct and complete and the patient gets better.

2. The diagnosis is correct, but the patient deteriorates because of the severity of the illness.

3. The diagnosis is partially correct or something else is going on so the patient stays the same or deteriorates.

4. The diagnosis is wrong, but the patient gets better anyway.

5. The diagnosis is wrong and the patient deteriorates.

When the patient is reassessed and has failed to improve or has deteriorated, the clinician's thinking should 'toggle' from intuitive to analytical with the possibilities described above in mind (Figure I).

This medical model of dual process theory and its operating characteristics have been described in further
TABLE 2 Demonstrable biases in the medical setting

\begin{tabular}{|l|}
\hline Gender $^{30-34}$ \\
\hline Race $^{35-40}$ \\
\hline Ethnicity $^{36-39}$ \\
\hline Obesity $^{41-44}$ \\
\hline Psychiatric illness \\
\hline Ag-48 \\
\hline Socioeconomic status $^{35,53}$ \\
\hline Sexual orientation \\
\hline Su-56 \\
\hline Substance abuse disorders \\
\hline Chronic and complex illness $^{58,59}$ \\
\hline
\end{tabular}

detail elsewhere. ${ }^{18,20,22,23}$ The key to well-calibrated decision making is to be in the right mode at the right time and experience is an important factor. ${ }^{24}$ The ability to realise which mode you are in (metacognition) and move from one to the other is also important. Generally, novices and trainees spend more time in the analytic mode, whereas the experienced clinician spends more time in the intuitive mode. Importantly, most biases and heuristics occur in the intuitive mode and this is where many of our thinking failures originate.

\section{PSYCHOLOGICAL FACTORS}

Analytical thought mostly follows the rules of logic and science, is relatively independent of context and is reproducible. Intuitive thought, in contrast, embraces a much wider range of thinking that may involve heuristics, biases, prejudices, emotion, passion, creativity, inspiration, lateral thinking, and other characteristics, as well as some hard-wired human behaviours such as have been described. ${ }^{18,25}$ It is less reproducible and highly context dependent. Cognitive and affective biases or 'dispositions to respond' (CDRs and ADRs) reside in our intuitions, are prevalent and especially relevant to clinical reasoning. More than 50 CDRs have been described, ${ }^{26,27}$ and about a dozen ADRs. ${ }^{28}$ Jenicek has recently expanded the cognitive biases list to more than $100 .{ }^{29}$ Examples of two CDRs, anchoring and search satisficing, are given in case study I overleaf, and the ADR fundamental attribution error in case study 2. ('Satisficing' is an amalgam of satisfy and sufficient. In conducting a search for information, clinicians will reach a point at which they are satisfied that a sufficient search has been done.) Examples abound of more familiar social biases in medicine (Table 2), and an example is given in case study 3 .

\section{DISCUSSION}

The abundance of biases raises the obvious question of how we can remain rational and yet be so fundamentally flawed in our thinking. How do we ever make a sensible decision? The answer probably lies in the fact that much of what we do is routine, predictable and requires little 


\section{CASE STUDY I}

A 45-year-old woman presents to the emergency department in an agitated state. She is holding a large empty bottle of aspirin and says that she has taken all of the pills a few hours ago to 'end it all'. Her breathing and heart rate are fast; she is nauseated and complains of ringing in her ears. Blood is drawn for testing that includes a toxic screen, intravenous lines are started and treatment is begun for salicylate poisoning. Within an hour, the laboratory reports that her salicylate level is at a toxic level.

Although her condition initially showed some marginal improvement, when she is reassessed by the emergency physician after two hours, the impression is that she is not progressing as well as expected. She now appears confused and her monitor shows a marked tachycardia. While the physician is reflecting on her condition, the patient's partner comes to the emergency department to enquire how she is doing. The physician tells him that she is not doing as well as expected but, given that she has taken a major overdose of salicylate, she may take a little time to stabilise. Her partner pulls an empty bottle of a tricyclic antidepressant out of his pocket and says that he found it on the bedroom floor when he got home from work. He wonders if this is important.

Shortly afterwards, the patient becomes hypotensive, with the monitor showing an intraventricular conduction delay with wide QRS, first-degree block and a prolonged QT interval; she then has seizures. She is intubated and transferred to the intensive care unit.

Comment: The case illustrates two cognitive dispositions to respond: anchoring and search satisficing. The emergency physician and nurses initially anchor on the patient's story, the empty bottle of salicylate, and the signs of acute salicylate toxicity. They do not enquire about any other medication she might have taken. The initial toxic screen measures only salicylate, acetaminophen and alcohol levels, and the initially high salicylate level confirms their belief that they are dealing with a salicylate toxidrome.

However, they have satisfied themselves that they were dealing with only a single toxicity and called off the search for any others. Had they asked the patient if she had taken anything else they might well have discovered the concurrent (and potentially more fatal) tricyclic overdose or might have detected tricyclics in a qualitative urine screen that would have alerted them to the possibility of concurrent toxicity.

\section{CASE STUDY 2}

A 28-year-old female patient is sent to an emergency department from a nearby addictions treatment facility. Her chief complaints are anxiety and chest pain that has been going on for about a week. She is concerned she may have a heart problem. An electrocardiogram is routinely done at triage.

The emergency physician who signs up to see the patient is well known for his views on 'addicts' and others with 'selfinflicted' problems who tie up busy emergency departments. When he goes to see the patient he is informed by the nurse that she has gone for a cigarette. He appears angry and verbally expresses his irritation to the nurse. He reviews her electrocardiogram, which is normal.

When the patient returns he admonishes her for wasting his time and after a cursory examination informs her she has nothing wrong with her heart and discharges her with the advice that she quit smoking. His discharge diagnosis is 'anxiety state'.

The patient is returned to the addictions centre where she continues to complain of chest pain but is reassured that she has a normal cardiogram and has been 'medically cleared' by the emergency department. Later in the evening she suffers a cardiac arrest from which she could not be resuscitated. At autopsy, multiple small emboli were evident in both lungs with bilateral massive pulmonary saddle emboli.

Comment: This is an example of the affective disposition to respond fundamental attribution error.The physician focuses on the disposition of the patient rather than the circumstances that led her into addiction. She had a long history of physical and sexual abuse. His anger at the patient further distracts him from his usual practice of reviewing medications and noticing on her triage chart that she is on a birth control pill and that she is a smoker.

\section{CASE STUDY 3}

A 32-year-old female presents to the emergency department with complaints of abdominal pain and vomiting. She is black, obese, schizophrenic and has poor personal hygiene. She does not communicate very well. She is treated with intravenous fluids, analgesics and anti-emetics. Her blood work-up and urinalysis are within normal limits.

A diagnosis of gastroenteritis is made and she is mobilised for discharge, but she begins to vomit again. It is getting late in the evening and the emergency physician decides to keep her overnight and arranges an ultrasound of her abdomen and repeat blood work for the morning.

The following morning, the ultrasound is reported as normal, but her white cell count has gone up to $13,000 /$ $\mathrm{mm}^{3}$. Abdominal $X$-rays are done and appear normal. Her condition does not improve through the day and in the late afternoon a computed tomography exam of her abdomen reveals a four-inch-long metallic/plastic foreign body, a hair clasp, in her stomach. This is removed several hours later by endoscopy.

Comment: From the outset, the patient had a number of likely biases operating against her. She is black, obese, schizophrenic and has poor hygiene. History taking is cursory and her physical examination limited and inadequate. She was not undressed fully for her diagnostic imaging exams and several artefacts (belt buckle, bra hardware and some clips) were evident on the $\mathrm{X}$-ray, which presumably contributed to the hair clasp being missed.

It took a total of 28 hours in the emergency department before the correct diagnosis was made. There were four handovers during the course of her stay in the emergency department, characterised by a poor management plan and one of the physicians being dismissive of the patient's complaints. Further history taken later revealed that she had a history of self-harm and swallowing foreign objects. 
TABLE 3 De-biasing strategies to reduce diagnostic error

\begin{tabular}{|c|c|}
\hline Strategy & Mechanism/action \\
\hline Develop insight/awareness & $\begin{array}{l}\text { Understand the nature, limitations and operating characteristics of the two principal modes of } \\
\text { thinking. Be aware that most biases occur in the intuitive mode. Provide detailed descriptions and } \\
\text { thorough characterisations of known cognitive and affective biases, together with multiple clinical } \\
\text { examples illustrating their adverse effects on decision making and diagnosis formulation. }\end{array}$ \\
\hline Consider alternatives & $\begin{array}{l}\text { Establish forced consideration of alternative possibilities, e.g. the generation and working through } \\
\text { of a differential diagnosis. Encourage routinely asking the question:What else might this be? }\end{array}$ \\
\hline Metacognition and reflection & $\begin{array}{l}\text { Train for a reflective approach to problem solving: stepping back from the immediate problem to } \\
\text { examine and reflect on the thinking process (analytical monitoring of intuition and double checking). }\end{array}$ \\
\hline Decrease reliance on memory & $\begin{array}{l}\text { Improve the accuracy of judgements through cognitive aids: mnemonics, clinical practice } \\
\text { guidelines, algorithms, personal digital assistants. }\end{array}$ \\
\hline Specific training & $\begin{array}{l}\text { Identify quantitative flaws and biases in thinking and provide directed training to overcome } \\
\text { them: e.g. instruction in fundamental rules of probability, distinguishing correlation from } \\
\text { causation, basic Bayesian probability theory. }\end{array}$ \\
\hline Simulation & $\begin{array}{l}\text { Develop mental rehearsal,'cognitive walkthrough' strategies for specific clinical scenarios to } \\
\text { allow cognitive and affective biases to be made and their consequences to be observed and } \\
\text { appreciated. Construct clinical training videos contrasting incorrect (biased) approaches with } \\
\text { the correct (de-biased) approach. }\end{array}$ \\
\hline Cognitive forcing strategies & $\begin{array}{l}\text { Develop generic and specific strategies to avoid predictable bias in particular clinical situations. } \\
\text { Promote use of forcing functions and checklists. }\end{array}$ \\
\hline Make task easier & $\begin{array}{l}\text { Gather more information about the specific problem to reduce task difficulty and ambiguity. } \\
\text { Make available rapid access to concise, clear, well-organised information, e.g. medical history, } \\
\text { discharge summaries, current medications. }\end{array}$ \\
\hline Minimise time pressures & $\begin{array}{l}\text { Provide adequate time for quality decision making. Minimise interruptions and distractions and } \\
\text { other sources of attentional capture. }\end{array}$ \\
\hline Accountability & $\begin{array}{l}\text { Establish clear accountability and follow-up for decisions made. It should always be clear who is } \\
\text { responsible for decisions that are made. }\end{array}$ \\
\hline Feedback & $\begin{array}{l}\text { Provide as rapid and reliable feedback as possible to decision makers so that errors are immediately } \\
\text { appreciated, understood and corrected, resulting in better calibration of decision makers. }\end{array}$ \\
\hline Maintain cognitive skills & $\begin{array}{l}\text { Be aware that whatever higher level cognitive skills are acquired need regular rehearsal and } \\
\text { maintenance. Clinicians should not trust themselves to stay up to date. Besides taking regular } \\
\text { refresher courses to maintain knowledge currency, they should use external validation of } \\
\text { cognitive skills and performance. }\end{array}$ \\
\hline
\end{tabular}

Adapted from Croskerry. ${ }^{26}$

in the way of analytic thought. In reality, we spend less time thinking rationally than we might think.

In order to make a rational decision we need to be fully informed about all the relevant information and, as we are well aware, this is rarely the case in medicine. There is always an irreducible uncertainty. James Reason, in Human error, ${ }^{60}$ nicely describes this as 'the cognitive reality departing from the formalised ideal' when he discusses 'flesh and blood' decision making, that is, the real decision making that occurs at the interface between clinician and patients, when resources are limited, time is short, cognitive effort is being rationed and shortcuts are sought. Under these circumstances, thinking analytically may be the exception as, for the most part, we are 'getting by' in the intuitive mode. This is captured in the iceberg metaphor: 'Cognitive thought is the tip of an enormous iceberg. It is the rule of thumb among cognitive scientists that unconscious thought is $95 \%$ of all thought - this $95 \%$ below the surface of conscious awareness shapes and structures all conscious thought.' ${ }^{61}$ In unconscious, intuitive thought reside heuristics (mental shortcuts, maxims, rules of thumb), and the readily available (cognitively miserly) other shortcuts offered by labelling, stereotyping, prejudices, and biases.

Some have suggested that the demonstration of such widespread cognitive biases must lead to the conclusion that 'our cognitive machinery contains deep defects in design'. ${ }^{62}$ However, evolutionary psychologists have argued, instead, that many biases in human information processing should not be viewed as 'errors' but rather as the product of the evolutionary processes that were necessary to solve specific adaptation challenges in our ancient environments. What has been necessary to move our genes forward over the past hundreds of thousands of years, may not now appear so adaptive in an environment that has changed dramatically in the past 10,000 years. $^{63}$ 
TABLE 4 Strategies for improving intuitive performance

\begin{tabular}{|c|c|}
\hline $\begin{array}{l}\text { Optimise } \\
\text { decision-making } \\
\text { environment }\end{array}$ & $\begin{array}{l}\text { Good decision making comes from good environments. They should be well designed, ergonomically } \\
\text { sound, with minimal interruption or distractions. They should provide expert, high level tutoring and } \\
\text { mentoring, and rich opportunities for practice and development of domain-specific skills. }\end{array}$ \\
\hline & $\begin{array}{l}\text { edback should occur as soon as possible and be objective, relevant, accurate, unambiguous and reliable. It } \\
\text { ould not be simply 'good' or 'bad' but rather should detail multiple attributes of the skill that is under focus. }\end{array}$ \\
\hline $\begin{array}{l}\text { Impose ci } \\
\text { breakers }\end{array}$ & $\begin{array}{l}\text { Train individuals to be able to recognise, screen and censor their intuitive thoughts and actions. } \\
\text { Encourage learners to be reflective, sceptical, to routinely challenge and to seek dis-confirming evidence. }\end{array}$ \\
\hline $\begin{array}{l}\text { Acknowledge } \\
\text { emotions }\end{array}$ & $\begin{array}{l}\text { Encourage awareness of and insight into emotions. Recognise the cues of visceral arousal and treat emotions } \\
\text { as data. Postpone decisions in hot emotional contexts. Recognise that positive affect is associated with relaxation } \\
\text { and openness to new ideas. Promote ability to infer emotional states of others and use this information. }\end{array}$ \\
\hline $\begin{array}{l}\text { Explore } \\
\text { connections }\end{array}$ & $\begin{array}{l}\text { Avoid rigid, pre-programmed reactions. Configure and reframe the problem in different ways. Try to think of } \\
\text { things that cannot be seen rather than what is immediately apparent. Allow alternatives to stereotypical, logical } \\
\text { analysis. Be imaginative in exploring connections outside the framework in which the problem is presented. } \\
\text { Use narrative, metaphor and analogies to make connections between difference aspects of the problem. }\end{array}$ \\
\hline $\begin{array}{l}\text { Accept conflict } \\
\text { in choice }\end{array}$ & $\begin{array}{l}\text { Recognise bounded rationality of decision making. Accept that there will often be uncertainty and } \\
\text { conflict in any choice made. Identify emotional vs computational sources of conflict. Recognise when } \\
\text { influence of sunk cost (already incurred, irrecoverable costs) and status quo biases are operating. Use } \\
\text { 'worst case scenario' as a reference point for perspective. }\end{array}$ \\
\hline $\begin{array}{l}\text { Make scientific } \\
\text { method intuitive }\end{array}$ & $\begin{array}{l}\text { Develop and practice cognitive forcing functions to avoid common pitfalls to the point that it becomes } \\
\text { second nature (intuitive) to use them. Make it a habit to use cognitive decision aids (clinical guidelines, } \\
\text { algorithms, clinical pathways, reliable sources) rather than trusting intuitions. }\end{array}$ \\
\hline
\end{tabular}

Adapted from Hogarth. ${ }^{64}$

TABLE 5 Stages of critical thinking

\begin{tabular}{|c|c|c|}
\hline Level & Attributes & Deficiencies \\
\hline $\begin{array}{l}\text { I. } \\
\text { Unreflective } \\
\text { thinker }\end{array}$ & $\begin{array}{l}\text { May have developed multiple skills in thinking but } \\
\text { unaware of them. }\end{array}$ & $\begin{array}{l}\text { Unaware of determining role that thinking plays in } \\
\text { their lives. Such skills as have been developed are } \\
\text { inconsistently applied due to lack of self-monitoring } \\
\text { of thought. Prejudices and misconceptions often } \\
\text { undermine quality of thinking. }\end{array}$ \\
\hline $\begin{array}{l}2 . \\
\text { Challenged } \\
\text { thinker }\end{array}$ & $\begin{array}{l}\text { Aware of the important role of thinking and that problems } \\
\text { may lead to serious outcomes. Basic grasp of necessary } \\
\text { standards of clarity, accuracy, precision, relevance, logic } \\
\text { and how to attain them. Aware of need for deliberative, } \\
\text { reflective thinking. Aware of role of self-deception. }\end{array}$ & $\begin{array}{l}\text { Unable to identify causative factors underlying flawed } \\
\text { thinking. Limited skills but often overconfident in } \\
\text { abilities. In need of a framework for understanding } \\
\text { how thinking works, and the factors that influence it. }\end{array}$ \\
\hline $\begin{array}{l}\text { 3. } \\
\text { Beginning } \\
\text { thinker }\end{array}$ & $\begin{array}{l}\text { Begins to take active control across multiple domains. } \\
\text { Recognises basic problems and need to internalise } \\
\text { and use standards. Begins to monitor own thoughts, } \\
\text { but sporadic. Begins to recognise egocentric thought } \\
\text { in themselves and others, and intellectual humility. }\end{array}$ & $\begin{array}{l}\text { Lack of plan to deal with basic problems. No } \\
\text { systematic strategies to solve thinking problems. Need } \\
\text { to know value of practice, training and good habits. }\end{array}$ \\
\hline $\begin{array}{l}4 . \\
\text { Practising } \\
\text { thinker }\end{array}$ & $\begin{array}{l}\text { Recognition that problems exist in their thinking and } \\
\text { awareness of habits needed to take charge of their } \\
\text { thinking. Evidence of active organisation of thinking in } \\
\text { some areas, especially in dealing with own egocentricities. }\end{array}$ & $\begin{array}{l}\text { Limited insight into deeper levels of thought. Often } \\
\text { unsuccessful at thinking in a variety of domains. Still } \\
\text { limited ability to monitor and realistically critique } \\
\text { own thoughts. }\end{array}$ \\
\hline $\begin{array}{l}5 . \\
\text { Advanced } \\
\text { thinker }\end{array}$ & $\begin{array}{l}\text { Good thinking habits now established and working. } \\
\text { Intellectually humble and actively self-monitors } \\
\text { and analyses thinking in all significant domains. } \\
\text { Continuously strives for fair-mindedness. Aware of } \\
\text { egocentric thought and strategies against it. }\end{array}$ & $\begin{array}{l}\text { Not yet consistent at a high level across all domains } \\
\text { of thinking. Occasional lapses into egocentricity, } \\
\text { sociocentric and one-sided reasoning. }\end{array}$ \\
\hline $\begin{array}{l}\text { 6. } \\
\text { Accomplished } \\
\text { thinker }\end{array}$ & $\begin{array}{l}\text { Systematically takes charge of thinking and strives for } \\
\text { improvement. Has developed capacity to intuitively } \\
\text { assess thinking for clarity, accuracy, precision, } \\
\text { relevance, logic etc. High degree of intellectual humility, } \\
\text { integrity, perseverance, courage, empathy, autonomy, } \\
\text { responsibility and fair-mindedness. }\end{array}$ & \\
\hline
\end{tabular}

From Elder and Paul.65 
Given that we spend so much of our time in the intuitive mode, where most of our thinking failures originate, one of the major challenges is to de-bias our thinking. Cognitive and affective de-biasing strategies are listed in Table 3. We should also attempt to create conditions under which intuitive thinking might be more reliable, as Hogarth has proposed (Table 4). ${ }^{64}$ Many of these strategies are aimed at learners and novitiates, but there is important work to be done with clinicians already in practice. According to Elder and Paul, the attainment of higher critical thinking skills passes through six levels of competence (Table 5). ${ }^{65}$ From the descriptors given, few clinicians would probably put themselves much further than level 2-4 in their current performance.

\section{CONCLUSION}

The ways in which physicians think is an extremely important part of providing safe healthcare, especially around timely and correct diagnosis. We now have a new model of decision making that clearly delineates

\section{REFERENCES}

I Schiff G, Hasan O, Kim S et al. Diagnostic error in medicine: analysis of 583 physician-reported errors. Arch Intern Med 2009; 169: 1881-7. doi:10.1001/archinternmed.2009.333

2 Brennan TA, Leape LL, Laird NM et al. Incidence of adverse events and negligence in hospitalized patients: results of the Harvard Medical Practice Study I. N Engl J Med 199I; 324:370-6. doi:I0.1056/NEJMI99102073240604

3 Wilson RM, Runciman WB, Gibberd RW et al. The Quality in Australian HealthCare Study. Med J Aust 1995; 163:458-7I.

4 Thomas EJ, Studdert DM, Burstin HR et al. Incidence and types of adverse events and negligent care in Utah and Colorado. Med Care 2000; 38:26I-7I. doi:I0.1097/00005650-200003000-00003

5 Nimmo GR, Mitchell C.A preliminary audit of interruptions in intensive care: implications for patient safety.J Intensiv Care Soc 2008; 9:240-2.

6 Bakwin H. Pseudoxia pediatrica. N Engl J Med 1945; 232:691-7. doi:I0.1056/NEJMI94506|4232240 I

7 Nuland SB. How we die: reflections on life's final chapter. New York: Alfred A Knopf; 1994.

8 Redelmeier DA, Ferris LE, Tu JV et al. Problems for clinical judgement: introducing cognitive psychology as one more basic science. Can Med Assoc J 200I; 164:358-60.

9 Redelmeier DA, Tu JV, Schull MJ et al. Problems for clinical judgement: 2. Obtaining a reliable past medical history. Can Med Assoc J 2001; 164: 809-13.

I0 Schull MJ, Ferris LE, Tu JV, et al. Problems for clinical judgement: 3. Thinking clearly in an emergency. Can Med Assoc J 200 I; I64:647-5I.

II Tu JV, Schull MJ, Ferris LE et al. Problems for clinical judgement: 4 Surviving in the report card era. Can Med Assoc J 2001; I64:1709-12.

12 Redelmeier DA, Cialdini RB. Problems for clinical judgement: 5 Principles of influence in medical practice. Can Med Assoc J 2002; 166:1680-4.

13 Anderson WA, Harris IB, Elstein AS. Skeptic, scholar, teacher and mentor. Adv Health Sci Educ Theory Pract 2003; 8:173-82. doi:I0.1023/A:1024959610762

14 Elstein AS. Thinking about diagnostic thinking: a 30-year perspective. Adv Health Sci Educ Theory Pract 2009; 14:7-18. doi: 10.1007/s 10459-009-9/84-0

15 Montgomery K. How doctors think: clinical judgment and the practice of medicine. New York: Oxford University Press; 2006.

16 Groopman J. How doctors think. New York: Houghton Mifflin Company; 2007. two types of thinking. The dual process model provides insight into the daily business of decision making. It describes the characteristics of each mode and its limitations. The model can be readily taught to those in training.

We need to be aware that much of our cognitive time is spent in the intuitive mode, where heuristics and biases preponderate. Physicians should appreciate that they are just as vulnerable to bias in this mode as others are.

A number of strategies have been proposed to help de-bias ourselves in decision making and to improve our performance in the intuitive mode. Together, they can lead to better calibrated decision makers and an improved level of safety for patients.

17 The first Diagnostic Error Meeting (DEM) was held in Phoenix, Arizona (2008), the second in Los Angeles (2009), the third in Toronto, Canada (2010), and the fourth will be in Chicago in $20 \mathrm{II}$.

18 Croskerry P. Clinical cognition and diagnostic error: applications of a dual process model of reasoning. Adv Health Sci Educ Theory Pract 2009; |4:27-35. doi:| 0.1007/s 10459-009-9182-2

19 Dawson NV. Physician judgment in clinical settings: methodological influences and cognitive performance. Clin Chem 1993; 39:1468-80.

20 Croskerry P. The theory and practice of clinical decision making. Can J Anesth 2005; 52:RI-8. doi:I0.1007/BF03023077

21 Evans JS. Dual-processing accounts of reasoning, judgment, and social cognition. Annu Rev Psychol 2008; 59:255-78. doi:I0.1/46/ annurev.psych.59.103006.093629

22 Croskerry P. A universal model for diagnostic reasoning. Acad Med 2009; 84: 1022-8. doi:10.1097/ACM.0b0 I 3e3 I 8Iace703

23 Croskerry P. Context is everything or how could I have been that stupid? Healthc Q 2009; 12 (Spec No Patient):e I7I-6.

24 Pretz JE. Intuition versus analysis: strategy and experience in complex everyday problem solving. Mem Cognit 2008; 36:354-66. doi: I0.3758/MC.36.3.554

25 Buss D. Evolutionary psychology: the new science of mind. 4th ed. Englewood Cliffs, NJ: Prentice Hall; 20I I.

26 Croskerry $\mathrm{P}$. The importance of cognitive errors in diagnosis and strategies to prevent them. Acad Med 2003; 78:I-6. doi:10.1097/00001888-200308000-00003

27 Croskerry P. Cognitive and affective dispositions to respond. In: Croskerry P, Cosby KS, Schenkel S et al., editors. Patient safety in emergency medicine. Philadelphia: Lippincott Williams \& Wilkins; 2008. p. 219-27.

28 Croskerry P, Abbass A, Wu A. Emotional issues in patient safety. J Patient Safety 20 I0; 6: I99-205. 10.1097/PTS.0b0 I 3e3 I8If6c0 Ia

29 Jenicek M. Medical error and harm: understanding, prevention and control. New York: Productivity Press; 201 I.

30 Franks P, Clancy CM. Physician gender bias in clinical decision making: screening for cancer in primary care. Med Care 1993; 31:2 I3-8. doi:10.1097/00005650-199303000-00003

3I Hamberg K, Risberg G, Johansson EE. Male and female physicians show different patterns of gender bias: a paper-case study of management of irritable bowel syndrome. Scand J Publ Health 2004; 32: |44-52. doi: I0.1080/|40349403 I001540 I

32 Borkhoff CM, Hawker GA, Kreder HJ et al. The effect of patients' sex on physicians' recommendations for total knee arthroplasty Can Med Assoc J 2008; I 78:68I-7. doi: I0.1503/cmaj.07। I 68 
33 Baumhäkel M, Müller U, Böhm M. Influence of gender of physicians and patients on guideline-recommended treatment of chronic heart failure in a cross-sectional study. Eur J Heart Fail 2009; I I:299-303. doi: I0.1093/eurjhf/hfn04 I

34 Risberg G, Johansson EE, Hamberg K. A theoretical model for analysing gender bias in medicine. Int J Equity Health 2009; 8:28. doi: I0.I I86/ I475-9276-8-28

35 Van Ryn M, Burke J.The effect of patient race and socio-economic status on physician's perceptions of patients. Soc Sci Med 2000 50:8I3-28. doi: 10.1016/S0277-9536(99)00338-X

36 Van Ryn M. Research on the provider contribution to race/ ethnicity disparities in medical care. Med Care 2002; 40(Suppl I) |40-5|. doi: |0.1097/00005650-20020|00|-000|5

37 Institute of Medicine. Unequal treatment: what healthcare providers need to know about racial and ethnic disparities in healthcare. Washington, DC: National Academy Press; 2002. Available from: http://www.nap.edu/html/unequal_treatment/reportbrief.pdf

38 Van Ryn M, Fu SS. Paved with good intentions: do public health and human service providers contribute to racial/ethnic disparities in health? Am J Public Health 2003; 93:248-55. doi:10.2105/ AJPH.93.2.248

39 Johnson RL, Saha S, Arbelaez JJ et al. Racial and ethnic differences in patient perceptions of bias and cultural competence in health care. J Gen Intern Med 2004; 19:101-10. doi:10.1III/ j. I525-1497.2004.30262.x

40 Green AR, Carney DR, Pallin DJ et al. Implicit bias among physicians and its prediction of thrombolysis decisions for black and white patients. J Gen Intern Med 2007; 22:|23|-8. doi:10.1007/s | |606007-0258-5

4I Hoppe R, Ogden J. Practice nurses' beliefs about obesity and weight related interventions in primary care. Int J Obes 1997; 2I:|4|-6. doi:I0.1038/sj.ijo.0800379

42 Hebl MR, Xu J.Weighing the care: physicians reactions to the size of a patient. Int J Obes Relat Metab Disord 200I; 25:1246-52. doi: I0.1038/sj.ijo.080168I

43 Bertakis KD, Azari R. The impact of obesity on primary care visits. Obes Res 2005; I3:1615-23. doi:10.1038/oby.2005.198

44 Robinson BE, Gjerdingen DK, Houge DR. Obesity: a move from traditional to more patient-oriented management. J Am Board Fam Pract 1995; 8:99-108.

45 Crisp AH, Gelder G, Rix S. Stigmatisation of people with mental illness. Br J Psychiatr 2000; 177:4-7. doi: I0.1 I92/bjp. I77.I.4

46 Mukherjee R, Fialho A, Wijetunge $A$ et al. The stigmatisation of psychiatric illness: the attitudes of medical students and doctors in a London teaching hospital. Psychiatr Bull 2002; 26:178-8I. doi: 10.1 192/pb.26.5.178

47 Lauber C, Nordt C, Braunschweig C et al. Do mental health professionals stigmatize their patients? Acta Psychiatr Scand Suppl 2006; 429:5 I-9. doi:I0. I I I I/j. I600-0447.2005.007I8.x

48 Daumit GL, Pronovost PJ, Anthony CB et al. Adverse events during medical and surgical hospitalizations for persons with schizophrenia. Arch Gen Psychiatry 2006; 63:267-72. doi:10.1001/archpsyc.63.3.267
49 Podolsky D, Silberner J. How medicine mistreats the elderly. US News World Rep 1993; I 14:72-6, 78-9.

50 Seniors discriminated against by healthcare system, says Alliance For Aging Research. San Antonio, TX: Senior Journal.com; 2003. Available from: http://www.seniorjournal.com/NEWS/Health/305-19healthcare.htm

5I Alliance for Aging Research. Ageism: how healthcare fails the elderly. Washington, DC: Alliance for Aging Research; 2003. Available from: http://www.agingresearch.org/content/article/detail/694/

52 Jacobson TA. Overcoming 'ageism' bias in the treatment of hypercholesterolaemia: a review of safety issues with statins in the elderly. Drug Saf 2006; 29:421-48. doi:10.2165/00002018200629050-00005

53 Fiscella K, Tancredi D. Socioeconomic status and coronary heart disease risk prediction. JAMA 2008; 300:2666-8. doi:10.100I/ jama.2008.792

54 Peterkin A, Risdon C. Caring for lesbian and gay people: a clinical guide. Toronto: University of Toronto Press; 2003.

55 Barbara AM, Quandt SA, Anderson RT. Experiences of lesbians in the health care environment. Women Health 200I; 34:45-62. doi:I0.1300/J0I3v34n0I_04

56 Scarce M. Smearing the queer: medical bias in the health care of gay men. Binghampton, NY: Harrington Park Press; 1999.

57 Merrill JO, Rhodes LA, Deyo RA et al. Mutual mistrust in the medical care of drug users: the keys to the 'narc' cabinet. J Gen Intern Med 2002; 17:327-33.

58 Yan J. Drug abuse treatment often addressed as afterthought Psychiatr News 2008; 43:9.

59 Evans M. Should doctors be able to cherry-pick patients? The Globe and Mail 9 Dec 2008. Available from: http://www. theglobeandmail.com/life/should-doctors-be-able-to-cherry-pickpatients/article726568/print/

60 Reason J. Human error. New York: Cambridge University Press; 1990.

6I Lakoff G, Johnson M. Philosophy in the flesh: the embodied mind and its challenge to western thought. New York: Basic Books; 1999.

62 Haselton, MG, Buss DM. Biases in social judgment: design flaws or design features? In: Forgas J, Williams K, von Hippel B, editors. Responding to the social world: implicit and explicit processes in social judgments and decisions. Cambridge: Cambridge University Press; 2003. p. 23-43.

63 Cosmides L, Tooby J. Consider the source: the evolution of adaptations for decoupling and metarepresentation. In: Sperber D, editor. Metarepresentation. New York: Oxford University Press; $200 \mathrm{I}$.

64 Hogarth RM. Educating intuition. Chicago: University of Chicago Press; $200 \mathrm{I}$

65 Elder L, Paul R. Critical thinking development: a stage theory with implications for instruction. Tomales, CA: Foundation for Critical Thinking; 2010. Available from: http://www.criticalthinking.org/ page.cfm?PagelD=483\&CategoryID $=68$

\section{SENIOR FELLOWS' CLUB PRIZE}

This prize of $£ 200$ will be awarded to the first-named (or corresponding) author of an original research paper on a clinical topic, deemed by a panel of judges to be the best paper by a doctor-in-training (i.e. pre-consultant level) published in the The Journal of the Royal College of Physicians of Edinburgh in $201 \mathrm{I}$.

Further details may be obtained from the Editorial Office, RCPE, 9 Queen Street, Edinburgh, EH2 IJQ, tel 0I3I 2473652 or email editorial@rcpe.ac.uk. 